\title{
実践研究
}

\section{手話などを用いた通常小学校における聴覚障害児への 授業援助の試み}

\author{
清 水 久美子・高 橋 信 雄
}

\begin{abstract}
通常学級における授業援助の望ましいあり方を探るために、小学校低学年の聴覚障害児を 対象に、授業場面で手話などを用いた「通訳」による授業援助を行った。この過程で、対象 児の注視行動と通訳者とのコミュニケーション行動は、対象児と通訳者との関係、通訳者の 配慮によって大きく変化した。これらの変化から、(1) 対象児の気持ちを受けとめ、応えるこ とで信頼関係を築く段階、(2)情報を求めているときに「通訳」を行う段階（対象児が「通訳」 の意味に気づく段階)、(3)キーワードを中心に「通訳」を行う段階（効果的に「通訳」を行う 段階)、の 3 段階が必要であることがわかった。このように、小学校低学年の児童を対象とし た手話などを用いる「通訳」は、段階に応じてきめ細かな対応が必要だと考えられる。しか し、今後の課題として、通訳の質的な評価も加える必要があると思われる。
\end{abstract}

キー・ワード：小学校低学年 聴覚障害児 授業援助 手話通訳

\section{I 、はじめに}

通常学級に在籍している聴覚障害児は、話しことば を中心にコミュニケーションを行っている。最重度の 聴覚障害児が、話しことばを中心とした学校生活を送 ろうとすると、補聴器をつけていても教師の指示やク ラスメートの発言などが聞き取りにくく、情報が不足 する。そのため、文字や手話といった視覚的な手段を 用いて情報を補償することが必要となる。視賞的な手 段による授業援助の方法としては、ノートテイク（筆 記通訳）と手話通訳の 2 通りがあると考えられる。文 字の場合、書くのに時間がかかり、また、読み取るの にも時間がかかる。これに対して、手話は、聴覚障害 児が使い慣れている場合、同じ内容を他の児童とほほ 同時に伝えることができるので、文字よりも効率的で ある。手話通訳については、次の 3 つの形態が考えら れる。(1) 聴覚障害児が在籍する学級の担任教師によ る通訳、(2) 聴覚障害児と同じクラスの児童による通 訳、(3) 専任の手話通訳者による通訳、である。ただし、 小学校に抢ける通訳は、教師の指示等の音声情報のみ でなく、周囲の状況や板書の内容などの情報提供を行

愛媛大学教育学部
うことが多いと予想されること、また、内容によって は絵や文字も利用する可能性があり、一般の手話通訳 とは異なるため、本研究では、手話通訳という用語に 代えて手話などを用いた「通訳」と記す。

次に、3つの「通訳」の形態について詳しくみてい く。

(1) 聴覚障害児の学級担任による「通訳」としては、 聴覚障害児を担当する保母が、ほとんどの生活情報を 手話で伝えたという実践報告がある（高橋, 1996)。高 橋は、通訳者の存在によって、非言語的コミュニケー ション（笑う、うなずくなど）がより多く引き起こさ れ、聴覚障害児がリラックスして言語活動に参加でき たと報告している。この報告では、聴覚障害児を担当 する保母が、手話や指文字を使用し、聴覚障害児とコ ミュニケーション手段を共有している。しかし、手話 の習得には多くの時間を要すため、現在の教育現場に おいて学級担任が手話を習得することは困難であり、 この方法を一般化することは難しいと予想される。

(2) 聴覚障害児に対して、同じクラスの児童が部分的 に「通訳」を行うことが考えられる。しかし、特定の 児童が聴覚障害児のために専属で「通訳」をすると重 荷に感じてしまい、聴覚障害児を避けるようになり、 
友達関係が壊れてしまったとの報告がある（馬場園， 1995）。特定の一人の览童に「通訳」の負担を強いると 児童自身の時間的・精神的余裕がなくなり、パニック 状態に陥るなどのトラブルが起こる可能性が指摘され ており、この方法も問題が大きいといえる。

(3) 専任の手話通訳者による「通訳」が考えられる。 しかし、小学校初期段階の聴覚障害児が第三者による 「通訳」という状況を受け入れられるかどうかは明確で はない。以上のように、いずれの方法も解決すべき問 題がある。

(3)の変形として、聴覚障害児と親しい人による「通 訳」が考えられるが、この場合、どのような効果があ り、問題があるのだろうか。清水 (1997 a, 1997 b)、 佐々木（1998）は、通常小学校に通う聴覚障害児に対 して、対象児と親しい学生ボランティアが授業に同席 し、文字や手話、指文字などを通して部分的に授業援 助を試みている。その結果、対象児は、学級担任やク ラスメートと積極的に関わるようになり、学級適応が 促進されるようになったとしている。

これらの試行研究にもとづいて、本研究では、小学 校低学年の聴覚障害児 1 名を対象に、手話などを用い た「通訳」による授業援助を試み、望ましい援助のあ り方を探る。対象児の行動の変化を通して、どのよう に「通訳」をすれば情報がよりょく伝わるのかを明ら かにし、あわせて、成人に対する手話通訳との違いを 検討する。

\section{II. 研究方法}

\section{1. 対 象}

Y.M. 児 (男児) を対象とし、小学 1 年 1 学期〜 3 年 1 学期の 2 年間 (平成 8 年 6 月〜 10 年 6 月) にわたり 観察した。

対象児の聴力およびコミュニケーションの状態は、 以下の通りである。

平均聴力レベルは、右耳が $97 \mathrm{~dB}$ 、左耳が $96 \mathrm{~dB}$ で、 補聴器を装用して聴覚の活用もしている。

健聴の両親のもとで 3 歳 4 か月から手話を取り入れ ているが、本児の手話の使用レベルは簡単な日常会話 ができる程度で、すべてのコミュニケーションを手話 で行っているわけではない。現在では、相手により手 話や身振り、音声言語などコミュニケーション・モー ドを使いわけている。

\section{2. 対象児を取り巻く環境}

対象児は, 松山市内の小規模校（1学年の学級数 2 クラス/学級内の児童数 28 人）に在籍している。担任
教師、クラスメートは毎年かわっており、クラス内で 手話は使われていない。対象児は、難聴学級において 国語、音楽の指導を、その他の教科の指導を通常学級 で受けている。

\section{3. 授業援助について}

1 人の特定の学生が、算数の授業場面で週 $2 \sim 3$ 回 の割合で、授業援助で行う。その際、教師の指示など の音声情報のみを「通訳」するのではなく、周囲の状 況や板書の内容など、対象児が必要としていると思わ れる情報の提供も心がける。「通訳」にあたっては、日 本語対応手話を用い、助詞は表さず、口話を併用する。 内容によっては絵や文字を利用する。

\section{4. 記録および分析方法}

通常学級における算数の授業 1 時間を対象児、教室 全体が写るように 2 台のカメラでそれぞれ録画する。 対象とした授業内容は、以下の通りである。

1 年 1 学期 (平成 8 年 6 月) :

「増えたり、減ったり」

2 学期前半 (平成 8 年 9 月) :

「問題を解こう」

2 学期後半（平成 8 年 11 月)：「大きな数」

3 学期（平成 9 年 1 月）：「ひろさくらべ」

2 年 1 学期 (平成 9 年 7 月):

「いろいろに考えよう」

2 学期（平成 9 年 12 月）：「かけ算」

3 年 1 学期 (平成 10 年 6 月) :

「コンパスを使って」

上記の授業について以下のような手順で分析を行 う。

1）録画場面の文字化：収録したVTRのなか から授業の導入とまとめの部分を中心に合計 20 分取 り出し、文字化し、この部分を分析対象とする。

2) 分析内容：授業における対象坚の行動につ いて文字化した記録をもとに、(1) 注視行動の変化、

(2) 通訳者とのコミュニケーション行動の変化の 2 点 から分析を行う。

(1) 対象児の注視行動の変化：対象児の注視行動 を、高橋（1996）の研究を参考に、以下の 3 つの項目 に分類する。他の指標は授業における変化要因が多 く、統制できないため、注視行動のみを指標とする。

・“前を見る”：教師や黒板を見た場合

・“通訳者を見る”：通訳者を見た場合

・“周囲を見る”：発表者や周囲の览童を見た場 合

観察期間を通しての変化傾向を検討するために、1 
年 1 学期〜 3 学期は $2 \sim 3$ か月ごとに、それ以降 3 年 1 学期までは 6 か月ごとに各注視行動の 1 回あたりの平 均時間を比較する。

(2) コミュニケーション行動の変化：対象児と通 訳者とのコミュニケーション行動を高橋（1996）の研 究を参考にして、以下の 3 つの項目に分類し、分析時 間内における各行動の出現回数と総時間を比較する。

・“通訳”：対象児が手話などによる通訳を受け た場合

・“質問”：対象児が、通訳者に対して授業の内 容について尋ねた場合

・“会話”：対象児が、通訳者に対して授業とは 関係のない話をした場合

\section{III. 結 果}

\section{1. 対象児の注視行動の変化}

Fig. 1 に注視行動の変化を、観察時期ごとに 1 回あ たりの平均時間で示す。

“前を見る”時間は学期の移行とともに増加し、2 年 2 学期には 17.2 秒となり、それまでより 3 倍以上 に増えており、3 年 1 学期になっても 17.4 秒とその まま維持している。“周囲を見る”時間は、 1 年 2 学期 までに 2.5 秒から 1.4 秒へと減少している。その後、
2 年 2 学期には 9 秒へと增加している。この時期、発表 しているクラスメートに注目するようになっており、 それが “周囲を見る”時間を増加させているといえる。 一方、“通訳者を見る”時間は、 1 年 2 学期後半までに 5.4 秒から 15.1 秒と増加するが、その後、2 年 2 学期 までに 4.1 秒へと減少し、3 年 1 学期には 19 秒と再 び増加している。

以上のように、 1 年 2 学期後半までは “通訳者や前 を見る”時間は増加傾向にあり、“周囲を見る”時間 は徐々に減少している。その後、2 年 2 学期までは“通 訳者を見る”時間は減少傾向に、“前や周囲を見る”時 間は増加傾向にあり、3 年 1 学期にはどの注視行動も 増加している。これらのことから、1 年 2 学期後半、 2 年 2 学期を境に対象児の注視行動が変化したことがわ かる。

初期の段階 (1 年 1 学期から 2 学期後半) で “通訳者 を見る”時間が増加したのは、通訳者との信頼関係を 成立させるため、通訳者が対象児の発信に十分応えら れるよう常に配慮したためではないかと思われる。そ の後 ( 1 年 3 学期〜 2 年 2 学期)、“前や周囲を見る”時 間が増加したが、これは、自ら情報を得ようと教師の 動きや周囲の状況に注意を向けるようになったため であろう。これに対して、“通訳者を見る”時間は 1

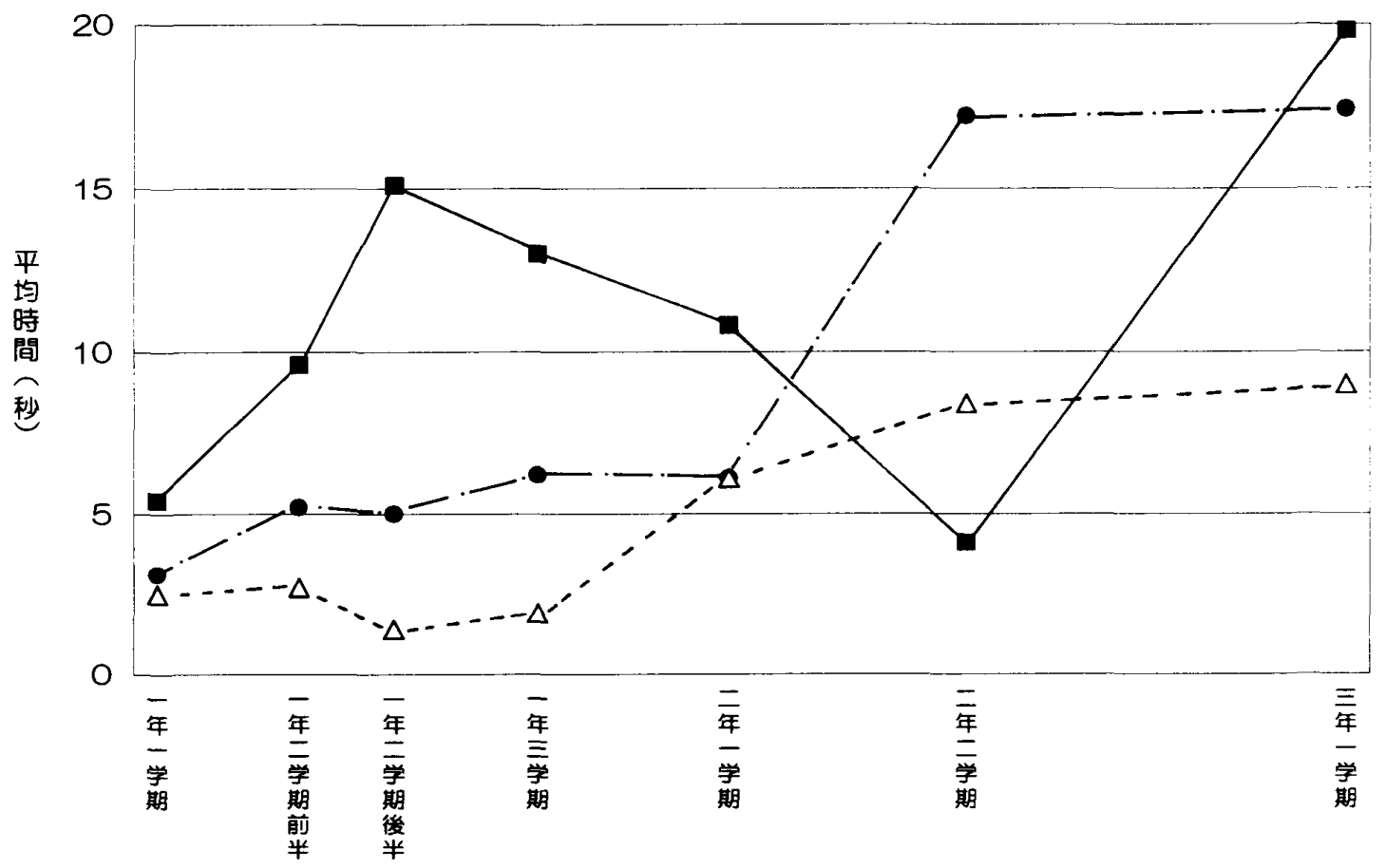

察 時期

Fig. 1 注視行動の変化（平均時間）

通訳者を見る，○前を見る， $\triangle$ 周囲を見る. 
度減少し、3 年 1 学期になると急激に増加している。 これは、“前や周囲を見る”行動からだけでは得られ る情報が不十分であることに気づき、必要な情報を補 うために通訳者を見て「通訳」を要求するようになっ たためではないかと思われる。また、通訳者が対象览 の主体性を尊重し、1 年 2 学期後半から対象児が通訳 者を見たときにのみ「通訳」を行うようにしたことも 関係していると思われる。このように、3 年 1 学期に 扔ける対象児の“通訳者を見る”行動の増加は、通訳 者との関係を成立させるための導入初期の増加傾向と は質的に大きく異なっているといえる。また、 3 年 1 学期には、いずれの注視行動も観察期間中、最大とな っており、授業に集中できるようになってきていると 思われる。

以上のように、対象児の注視行動は時期とともに変 化しており、その変化の仕方は注視行動の項目により 異なっている。特に“通訳者を見る”行動は、変化が 大きく、 1 年 2 学期後半以降、 1 度減少し、3 年 1 学期 になって再び増加に転じている。この減少のあとの増 加は、対象児が「通訳」の必要性を強く感じ始めたか らではないかと考えられる。

次に、対象児と通訳者とのコミュニケーション行動
を観察時期ごとに比較する。

\section{2. 通訳者とのコミュニケーション行動の变化}

Fig. 2 に、観察時期ごとにコミュニケーション行動 の回数を、Fig. 3 にコミュニケーション行動の総時間 を示す。

コミュニケーション行動の回数 (Fig. 2) を比較する と、“通訳”の回数は、1 年 2 学期には 14 回から 6 回に 隇少し、その後、3 年 1 学期には 20 回と増加してお り、 1 年 2 学期後半が最小になる谷型の変化が認めら れる。“質問”の回数は、1 年 1 学期にはみられず、 2 学 期後半の 8 回まで増加したあと、2 年 2 学期の 5 回ま で徐々に減少し続け、 3 年 1 学期には 11 回と再度増 加している。一方、“会話”の回数は 1 年 2 学期後半に は26回と急激に増加し、その後、減少傾向が続き、2 年 1 学期以降の回数はかなり少ない。

次に、コミュニケーション行動の総時間 (Fig. 3) を 比較する。“通訳”は、1 年 2 学期前半に一度増加した あと、2 年 2 学期まで減少し続け、3 年 1 学期には 396 秒と急激な増加を示している。“会話”は、1 年 2 学期 後半には 86 秒から 492 秒と約 6 倍増加している。ま た、“質問”は、1 年 3 学期まで徐々に増加し続けたあ と、 2 年 2 学期まで減少し続け、 3 年 1 学期には急激に

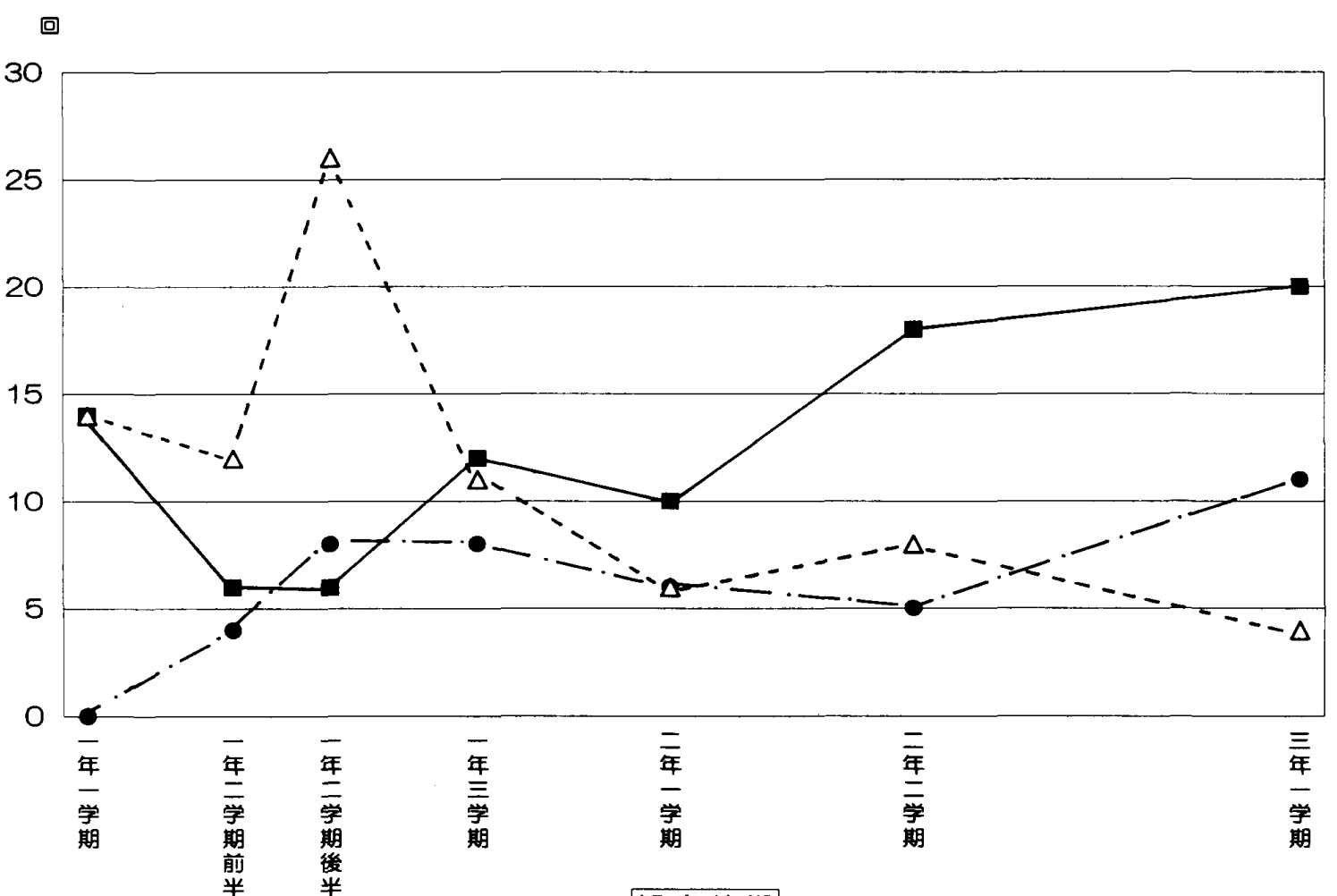

辇察 時 期

Fig. 2 コミュニケーション行動の回数の変化

通訳, 質問, $\triangle$ 会話. 
増加している。

以上のように、1 年 2 学期後半には、“会話”、“質問” の回数・総時間とも増加しており、“会話”が全体の 50 \%以上を占めるようになっている。通訳者が対象児の 発信を受けとめることで、対象児は、通訳者を一方的 な情報発信者ではなく、自分の話も聞いてくれる人、 わからないときに尋ねることができる人と認識してい ると思われる。

一方、“通訳”の回数は 1 度減少し、 1 年 3 学期から は増加傾向にある。これに対し、総時間は徐々に減少 している。これは、2 年 2 学期から通訳者がキーワー ドを中心に「通訳」を行ったために、「通訳」時間が短 縮されたものと思われる。 3 年 1 学期には 396 秒と平 成 9 年 12 月の 4 倍に増加したのは、対象児自身の授 業に対する集中力の高まりがあると考えられる。

以上のように、観察時期によって、通訳者とのコミ ュニケーション行動は質的に変化している。特に“会 話”が多い 1 年 2 学期後半、時間的に“通訳”、“会 話”、“質問”とも最も短い 2 年 2 学期を境として変化 がみられる。

3 年 1 学期の “通訳” “ “質問” の回数・総時間の急 激な増加は、効果的な「通訳」により情報を得ること
ができるようになり、わからないことは通訳者に質問 することで補うようになってきたためと思われる。

\section{IV. 考 察}

\section{1. 対象児の変化}

以上のように、対象児の注視行動や通訳者とのコミ ュニケーション行動は 1 年 2 学期後半、 2 年 2 学期を 境に変化しており、次の 3 つの時期にわけることがで きる。

第 I 期：通訳者との関係づくりの時期一「手話通 訳」の檤入（1 年 1 学期〜2 学期）

導入期では、対象児との信頼関係がないままに通訳 者が「通訳」を行ったために、対象児が途中で目をそ らすことが多く、「通訳」が成立していなかった。そこ で、対象児との信頼関係を築くために、対象児からの 発信を受けとめ、それに応えることにした。こうした 通訳者との関わりを通して、信頼関係が成立し、対象 児は、通訳者が自分の話を聞いてくれる人と認識して いったものと思われる。また、通訳者に対して積極的 に授業内容を尋ねるようになったことから、通訳者が 自分に対して「通訳」していることを理解し、自分に とって必要な存在として通訳者を捉えるようになった

秒

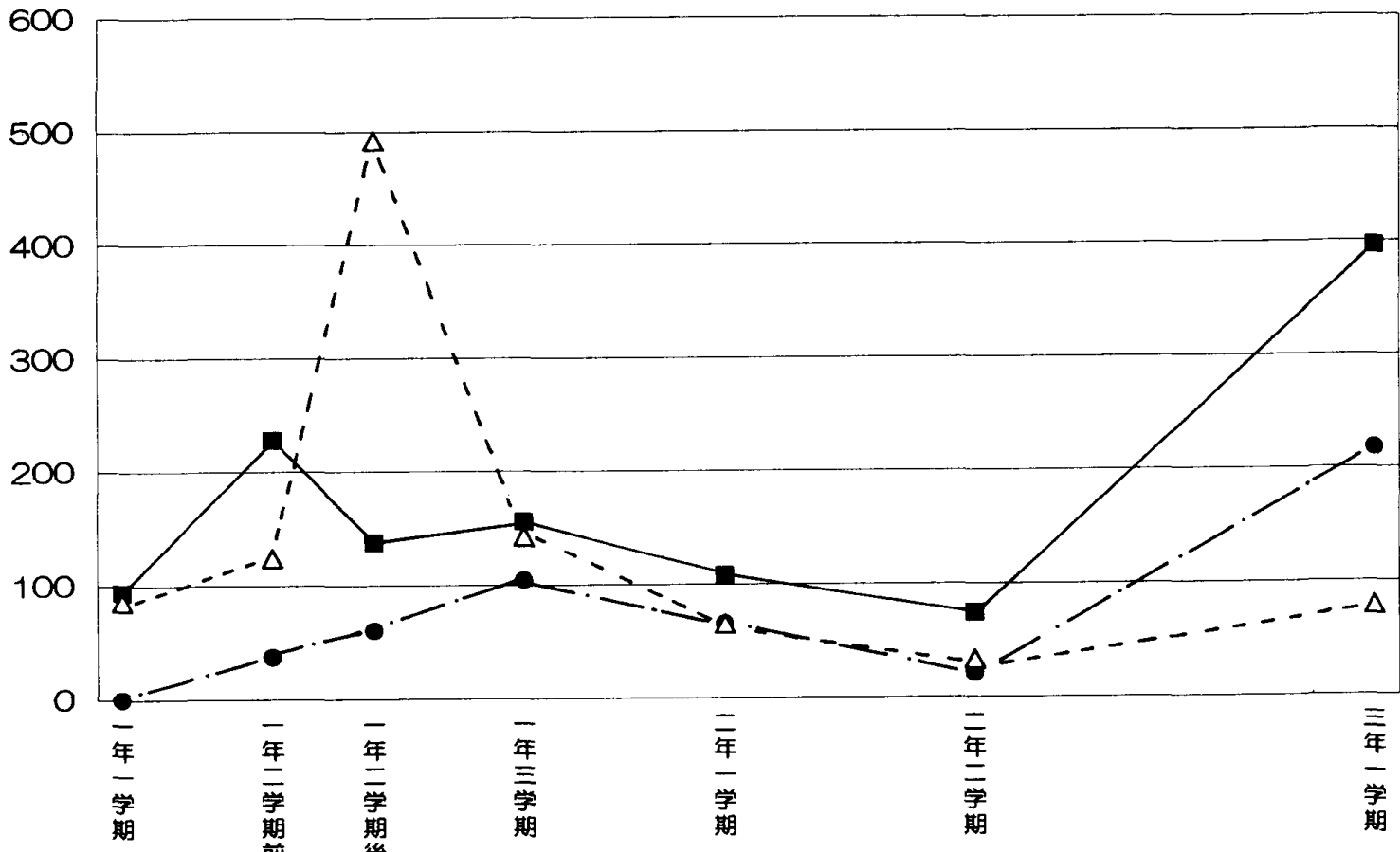

観察 時期

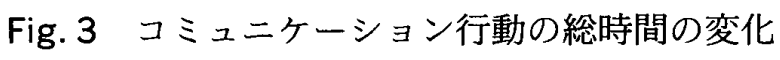


ものと思われる。

第II期：授業内容に注目する移行期一教師やクラ スメートに目を向ける（1 年 3 学期〜2 年 2 学期）

1 年 3 学期から、通訳者は、対象児の自主性を尊重 し、対象児が通訳者を見たときにのみ「通訳」を行う ようにした。そのため、通訳者を見る総時間は隇少し、 前や周囲を見る時間は増加したと思われる。このこと から、対象児は、次第に教師や周囲のクラスメートに 目を配り、自分の力で情報を得、授業内容に注目する ようになり、教師やクラスメートの様子だけでは内容 が理解できないときに通訳者を見ることで「通訳」を 要求し、情報を補うようになっていったものと思われ る。

第III期：効果的「通訳」の成立期一キーワードを中 心に「通訳」を行う（3 年 1 学期）

3 年 1 学期になると、どの注視行動も増加してい る。特に通訳者を見る時間が急激に増加している。こ れは、対象児が「通訳」の必要性を感じ、改めて通訳 者に注意を向けるようになったためと考えられる。一 方で、対象児が必要に応じて主体的に「通訳」を利用 し始めたことから、通訳者は、対象児が通訳者を見て いなくても、授業内容にあわせて、キーワードとなる ことばを手話で表しており、通訳者の対象児に対する 関わり方が変化している。

通訳者が手話でキーワードを提示し、「通訳」の役割 を強くしたことによって、情報を得るための方法の幅 が広がり、対象児は必要な情報を得るための方法を自 分なりに選択できるようになったと思われる。

\section{2. 児童期の「手話通訳」における留意点}

上述のような変化をもたらした主たる要因として、 対象児の発達と通訳者の関わり方が考えられる。そこ で、通訳者が関わる際の配慮をまとめると次のように なった。

「通訳」導入初期では、ただ通訳するだけではなく、 対象児との信頼関係を築くことが必要となる。そのた め、一方的に「通訳」を行うのではなく、(1) 通訳者に 対する伝えたいという対象児の気持ちを尊重し、受け とめ、(2)その気持ちに的確に応えることが必要であ る。通訳者との信頼関係が成立したあとは、通訳者の 顔を見るなど、(3) 情報がほしいと対象児が思っている ときにタイミングよく伝わるように「通訳」を行う。 さらに (4) 対象児が「通訳」を主体的に利用するため に、キーワードを中心に手話で提示することは効果的 である。このような授業援助により、対象児は、積極 的に授業に参加できるものと思われる。
このように、授業における小学校低学年の「通訳」 は成人に対する手話通訳とは大きく異なる。

小学校低学年の聴覚障害児に対して「手話通訳」を 行う際に、最も留意すべき点は、対象児と通訳者との 信頼関係を築くことである。対象児に情報を得ようと する意志や姿勢が育っていなければ、情報を受容した り、処理することができず、「通訳」自体を拒否する恐 れがある。また、担任教師と事前に話し合いを行うこ とも、教師の指導の意図を把握し、正確に授業内容を 「通訳」するために必要である。

さらに、対象児の語彙力や理解力を考慮して「通訳」 を行わなければならない。成人に対する通訳のように 話の内容に忠実な通訳 (松崎, 1991) を行うと、対象児 の語彙力や理解力を無視していることになり、対象児 が必要としている情報が伝わらない。通訳者は、対象 児の様子を正確に把握し、対象児の状態に応じて、教 師の指示などの音声情報のみでなく、周囲の状況など の情報も簡単なことばにいいかえたり、まとめたりし て伝えることも必要である。また、対象児が「通訳」 の役割に気づき、その必要性を感じるようになったと きに、キーワードとなることばを中心に伝えることは 効果的であり、「通訳」の主体的な利用につながると考 えられる。

以上のように、小学校低学年の聴覚障害児に対する 「通訳」は、通訳者の配慮や通訳の方法などにおいて、 その児の語彙力や授業内容の理解度、そのときの態度 などに応じて「通訳」を行うことが望ましい。そのた めに通訳者は、対象児の状態を正確に把握し、どんな 情報を必要としているのかを見極める必要がある。

\section{V.おわりに}

本研究から、小学校低学年の聴覚障害児に対して手 話などを用いた「通訳」による授業援助を行う際に、 対象児の状態に応じて、通訳者が関わりを変化させる ことで、効果的な「通訳」が可能になっていく過程が 明らかになった。

しかし、今回のように、対象児の授業における注視 行動を中心とした行動面の量的な評価だけでは、授業 援助の効果を十分に明らかにすることはできない。今 後、授業とは別の場面を設定し、通訳の内容（通訳者 の役割・位置、通訳の方法）や対象児の理解度のよう な質的な評価を加えて検討する必要がある。

\section{引用文献}

馬場園智子（1995）通常学級における手指による聴覚 
障害児への援助. 聾教育科学会第 37 大会資料集, 912

松崎理恵子（1991）手話通訳の技法. 神田和幸 (編), 手話通訳の基礎一手話通訳士をめざして一. 第一法 規, 307-321.

佐々木順二（1998）通常小学校における手話通訳の試 み一 $\mathrm{T}$ 览の事例から一. 愛媛大学特別専攻科修了論 文, 17-25.

清水久美子（1997a）通常小学校における聴覚障害児 への援助一手話通訳を通して一. 日本特殊教育学会 第 35 回大会発表論文集, 84-85.

清水久美子（1997b）通常小学校にお抢聴覚障害児 への援助一手話通訳の効果と対象児の変容一. 特別 なニーズ教育とインテグレーション学会第 3 回研究 大会発表要旨集録, 60-61.

高橋眞由美 (1996) 保育園の中の高度難聴児. 久保由 美子・高橋䢐由美・吉松靖文・長尾秀夫, 療育に関わ る各専門家の考え方についての研究 (第 3 報). 愛媛 大学教育学部障害児教育研究室紀要第, 20, 117-124.

\section{参考文献}

市田泰弘（1991）手話の基本的語彙. 神田和幸 (編), 手話通訳の基礎一手話通訳士をめざして一，第一法 規, 117-130.

井原栄二 (1996) 聴覚障害児の言語とコミュニケーシ ヨンの指導〜先人に学び，それを越えるもの〜. 愛 媛大学教育学部障害児教育研究室紀要, 20, 1-34.

宮野忠夫（1988）インテグレーションを考える一その 現状と課題一. 聴覚障害, 43(2), 4-7, 48.

中野聡子・吉野公喜・相良啓子 (1997) 聴覚障害児の インテグレーションに関する一考察一トライポッド モデルの事例から考える一. ろう教育科学, 39, 8999.

佐々木順二（1997）通常小学校における聴覚障害児へ の手話通訳の試み一 $\mathrm{T}$ 児の事例から一. 特別な二ー ズ教育とインテグレーション学会第 3 回研究大会発 表要旨集録, 64-65.

-1998. 6.3 受稿, 2001.4.21 受理一 